\title{
Academic Librarian Publishing Productivity: An Analysis of Skills and Behaviors Leading to Success
}

\section{Camielle Crampsie, Tina Neville, and Deborah Henry}

\begin{abstract}
Scholarly publishing continues to be a prominent expectation for many academic librarians. This survey explores characteristics, behaviors, motivations, institutional supports, and educational opportunities that help library practitioners become successful authors. It also looks at perceived confidence in research skills of both novice and experienced librarians. Many librarians show confidence in research activities related to their overall job assignments (literature searching, writing, and such) but find more sophisticated research skills, such as statistical analysis, more challenging. Findings indicate that having additional graduate research experience beyond the library degree, time-management skills, and collaboration with other researchers may provide useful benefits.
\end{abstract}

\section{Introduction}

In the last few decades there has been continuing interest regarding research expectations of academic librarians. ${ }^{1}$ Because the pressure to publish does not appear to be subsiding at many institutions, examining factors that may lead to increased academic librarian scholarly productivity is worthwhile. Several previous studies focus on librarians publishing at a particular institution. ${ }^{2}$ Others focus on journal analyses of top library and information science (LIS) journal titles to determine characteristics of authorship. ${ }^{3}$ A number of authors have attempted to determine benchmarks for publishing productivity by academic library practitioners, particularly by examining the most productive institutions. ${ }^{4}$ Studies call for more information on motivations and behaviors that might be common to prolific academic library researchers as well as analyses of barriers to research, particularly related to confidence in research skills. ${ }^{5}$ This exploratory study addresses those concerns by asking individual librarians to describe their own research skills as well as possible factors leading to their success in publishing peerreviewed articles. The following research questions are examined:

1) What motivations and institutional supports help academic librarian authors publish in peer-reviewed journals?

\footnotetext{
*Camielle Crampsie is Assistant Librarian, Research and Instruction Librarian, email: ccrampsie@usf.edu; Tina Neville is Librarian, Research and Instruction; and Deborah Henry is Librarian emeritus, all at the University of South Florida St. Petersburg. The authors would like to thank Bruce Neville for his thoughtful comments on the manuscript. (2020 Camielle Crampsie, Tina Neville, and Deborah Henry, Attribution-NonCommercial (http:// creativecommons.org/licenses/by-nc/4.0/) CC BY-NC.
} 
2) In what research skills do academic library authors (both novice and experienced) feel more or less confident?

3) Do library authors have common behaviors or research skills that lead to higher publishing productivity in scholarly journals?

Gaining more insights into these topics will help library schools prepare graduates to be more comfortable with their research skills, whether these skills are used for publication, instruction, or internal library assessment. In addition, this study may assist academic institutions in identifying the types of support beneficial for research and give guidance to novice library authors on what preparations may lead to successful research and publishing.

\section{Literature Review}

\section{Research Methods Training and Confidence in Research Skills}

Some believe there is an education gap for library practitioners, where librarians do not have the skills, knowledge, or confidence to conduct research. ${ }^{6}$ As of 2016, 62 percent of LIS degree programs accredited by the American Library Association (ALA) required a research methods course. ${ }^{7}$ Even with more than half of the LIS programs requiring a research methods course and providing a basic understanding of the research process, there seems to be a disconnect in fostering interest and confidence to do research. ${ }^{8}$ In a 2010 survey by Kennedy and Brancolini, 57 percent of librarians reported that their LIS degree prepared them to understand research articles but only 26 percent felt that it actually helped them to conduct research. ${ }^{9}$ In a 2015 follow-up survey, those who believed that their LIS degree helped prepare them to be researchers dropped to 17 percent. $^{10} \mathrm{~A}$ recent survey of early-career academic librarians also concluded that they could benefit from additional graduate training in research methods. ${ }^{11}$ Several studies support this idea, speculating that librarians who wrote a thesis or dissertation for a graduate degree find this process helped them learn skills and gain confidence to conduct and publish research. ${ }^{12}$

\section{Institutional Expectations and Support for Research}

Most tenure-earning academic librarians in North America are required to do research, and many non-tenure- earning librarians are expected or encouraged to publish. ${ }^{13}$ Many librarians work 12-month contracts and have library duties that make finding time to do research difficult. ${ }^{14}$ A number of studies discuss academic librarians' frustration in trying to find time for research. ${ }^{15} \mathrm{~A}$ recent survey of Irish academic librarians found that 21 percent listed lack of time as the reason that they hadn't published, and a survey of early-career academic librarians in the United States listed time as the greatest challenge to research. ${ }^{16}$ However, perception of research expectations and the influence of workload on time for research may vary. A 2010 survey of Canadian library directors and deans revealed that administrators felt research expectations were too low, while librarians felt expectations were either adequate or too high. The survey also found that administrators have a perception that librarians overestimate issues such as lack of time, funding, and support, yet they underestimate their lack of skills and motivation. ${ }^{17}$ Even when research leave is available, a large percent of research is conducted while still performing regular duties. Sabbaticals or research leave strongly support research productivity, but librarians may not be able to take advantage of that opportunity. ${ }^{18}$ Beyond formal allocations for research time, additional institutional support may come in the form of formal or informal mentoring, provision of statistical consultants, and opportunities for collaborations within the library or the institution. ${ }^{19}$ 


\section{Motivation to Conduct Research}

Tenure and promotion may be among the most significant motivators for many academic librarians to conduct research; however, they are not the only motivator, particularly after tenure or the highest level of promotion has been reached..$^{20}$ For some librarians at tenureearning institutions, continued research is expected in post-tenure reviews. ${ }^{21} \mathrm{~A} 2016$ survey of academic librarians illustrated that many post-tenure librarians are still motivated to publish. Described as "liberating," the publication process gives them the ability to pursue research topics that interest them while under less pressure to publish..$^{22}$ And many academic librarians, even those in nonfaculty positions, may feel obligated to add to the profession through publication. Others simply have a desire to grow professionally. ${ }^{23}$ Intrinsic motivations such as a sense of curiosity and enjoyment for doing research and writing can also be powerful motivators. ${ }^{24}$ Collaborating with others may increase motivation and confidence in doing research and provide the flexibility to do research in areas of interest regardless of one's career status or previous experience in publishing. ${ }^{25}$

\section{Research Productivity}

Research productivity, particularly for peer-reviewed articles, is often used as a measure of success when applying for tenure or promotion; even nonfaculty academic librarians may be encouraged to publish for annual review or career advancement. Numerous studies have attempted to provide data on what constitutes an average number of publications by librarians. ${ }^{26} \mathrm{~A}$ recent study by Hoffman, Berg, and Koufogiannakis assigned weights to various types of librarian research outputs, considering peer-reviewed journals and authored books to have the highest impact. ${ }^{27}$ According to Hollister, peer-reviewed articles are also regarded as the most desirable form of research publication. ${ }^{28}$ Opinions vary somewhat on what constitutes acceptable or high publishing productivity by academic librarians. An analysis of LIS journals from 2003 to 2012 found that an academic librarian author who published three or more articles within five years was in the top 8 to 9 percent. ${ }^{29} \mathrm{~A}$ study of Tennessee academic librarian publications between 2007 and 2011 found an average of 1.21 articles per author, with the most productive authors publishing 5 to 10 articles. ${ }^{30}$

\section{Methods}

This is an exploratory study meant to gain insight into characteristics, behaviors, motivations, institutional supports, and educational opportunities of academic librarians who publish. The publishing expectations and requirements for LIS faculty and for practitioners may be very different and their skills and behaviors may differ as well. The population being studied here is limited to practicing academic librarians who, for the purposes of this study, are defined as those librarians holding a Master of Library Science (MLS) degree and working in an academic library but who do not devote the majority of their time to teaching in a graduate LIS program. An online survey was created using a Google Docs form and distributed to a variety of library discussion lists of interest to academic librarians. ${ }^{31}$ Because of duplication among lists, a response rate could not be calculated; there is a possibility that the survey could have been taken multiple times. The survey instrument consisted of demographic, multiple-choice, checklist, and Likert scale questions. All questions included an opportunity for open-ended comments that were examined to look for common themes but were not coded to be statis- 
tically measurable. The survey was distributed in November 2017 and remained open for three weeks. A second request for participation was distributed to the same discussion lists to increase the response rate. All responses were anonymous and were downloaded into an Excel spreadsheet for analysis. To look for possible correlations, the Excel data were coded for SPSS and analyzed using a Pearson's chi-square test.

It is impossible to determine how much the opinions given in this survey are representative of the overall academic library profession. Although a major attempt was made to get the survey out to as many academic librarians as possible, there was no control over the selfselection of the respondents, many of whom were undoubtedly interested in the topic and had strong feelings about publishing. In addition, the responses were anonymous, so there is no way to determine which institutions are represented and how well they are balanced with the full North American academic library population.

Several studies have emphasized the importance of peer-reviewed articles over other kinds of research output in librarianship; so, considering the length of the survey, the authors decided to focus on publication of peer-reviewed articles only and did not ask questions about scholarly books, book chapters, or presentations. ${ }^{32}$ A question asking for the country of the participant's current institution was also included. Although the responses included participants from outside the United States and Canada, they were removed from the final analysis, as the sample size was too small $(n=2)$ to provide any meaningful analysis. After the survey data were cleaned to remove participants who did not meet the study criteria, 305 usable responses remained.

\section{Findings and Discussion}

Ninety-five percent of the respondents were from the United States, and five percent were from Canada. The large majority (92\%) work a 12-month contract, and an additional 7 percent identify themselves as full-time but with a contract of less than 12 months. Although the definition of faculty status varies from one institution to another, 75 percent of all respondents are considered faculty, with 56 percent of respondents being tenured or tenure track. The survey respondents were almost evenly divided between experienced faculty (defined as associate or full professors [47\%] or those with more than 10 years of experience [48\%]) and junior faculty (defined as assistant professor or "other" [53\%] or those with fewer than 10 years of experience [52\%]). Most respondents work in a doctoral granting institution (73\%), and 64 percent of all the survey participants are at institutions with more than 10,000 students. Nearly half $(49 \%)$ of all respondents were from institutions with large library faculties (defined as those with more than 15 MLS librarians). Table 1 provides additional demographic data.

\section{Research Methods Training and Confidence in Research Skills}

Participants were asked to comment on various methods that may have helped prepare them to conduct publishable research. A slight majority (55\%) have at least one graduate degree in addition to the MLS. Of the respondents, 18 percent conducted original research as part of their MLS curriculum, and 67 percent wrote a thesis or major research paper for their other graduate degrees. Slightly fewer than half of the respondents (48\%) were required to take a research methods course for their MLS degree, and an additional 11 percent selected research methods as one of their optional courses. One participant commented: "I have chaired the library's group for tenured and tenure-track librarians for several years. I have observed that 
librarians who have taken research methods course(s) are far more comfortable working toward tenure and get off to a more successful start."

To get a sense of the participants' confidence when it came to publishing peer-reviewed articles, they were asked to rate their comfort level when performing stages of a typical research process. The scale ranged from 1 to 5 , with 1 indicating pure panic at the thought of completing the step and 5 indicating feeling very confident in the task (see table 2). The results are listed in order of greatest perceived confidence (mean), not the order in which they were presented in the survey.

This study corroborates previous research showing that librarians seem most confident in areas related to their skills as librarians, such as performing a literature search and writing the manuscript, but lack confidence in such skills as analyzing data using statistical tests and writing a grant proposal. ${ }^{33}$ Many of the comments made by respondents of this study referred to a sense of optimism that confidence and better writing abilities come with time. The need for practice and keeping an open mind for constructive criticism were cited as key skills. As one respondent noted, "I have published a lot, and I feel very confident in my research abilities but it took a long time to get there. A lot of practice and rejection and more practice."

\begin{tabular}{|c|c|c|c|c|c|}
\hline \multicolumn{6}{|c|}{$\begin{array}{c}\text { TABLE } 1 \\
\text { Descriptive Analysis of Demographics }\end{array}$} \\
\hline \multicolumn{6}{|c|}{ Faculty Status $(n=305)$} \\
\hline $\begin{array}{l}\text { Faculty, tenured/ } \\
\text { continuing } \\
\text { contract }\end{array}$ & $\begin{array}{l}\text { Faculty, tenure- } \\
\text { track but not yet } \\
\text { tenured }\end{array}$ & $\begin{array}{l}\text { Professional or } \\
\text { administrative, } \\
\text { not faculty }\end{array}$ & $\begin{array}{l}\text { Faculty, } \\
\text { promotion } \\
\text { earning }\end{array}$ & $\begin{array}{l}\text { Faculty, not } \\
\text { promotion } \\
\text { earning }\end{array}$ & Other \\
\hline $30 \%(93)$ & $25 \%(77)$ & $22 \%(67)$ & $16 \%(49)$ & $3 \%(10)$ & $3 \%(9)$ \\
\hline \multicolumn{6}{|c|}{ Academic rank $(n=300)$} \\
\hline Full professor & $\begin{array}{l}\text { Associate librarian } \\
\text { /professor }\end{array}$ & $\begin{array}{l}\text { Assistant librarian } \\
\text { /professor }\end{array}$ & \multicolumn{2}{|c|}{$\begin{array}{l}\text { Instructor, visiting } \\
\text { professor, other }\end{array}$} & \\
\hline $19 \%(57)$ & $28 \%(84)$ & $34 \%(103)$ & $19 \%(56)$ & & \\
\hline \multicolumn{6}{|c|}{ Years as an academic practitioner $(n=305)$} \\
\hline 5 years or less & 6-10 years & 11-20 years & \multicolumn{2}{|l|}{$>20$ years } & \\
\hline $26 \%(80)$ & $26 \%(78)$ & $28 \%(84)$ & $21 \%(63)$ & & \\
\hline \multicolumn{6}{|c|}{ Institution type $(n=304)$} \\
\hline $\begin{array}{l}\text { ARL or CARL } \\
\text { (Doctoral) }\end{array}$ & $\begin{array}{l}\text { Doctoral but not } \\
\text { ARL or CARL }\end{array}$ & Master's only & $\begin{array}{l}\text { Baccalaureate } \\
\text { only }\end{array}$ & $\begin{array}{l}\text { Associate or } \\
\text { professional }\end{array}$ & Other \\
\hline $39 \%(118)$ & $34 \%(104)$ & $13 \%(40)$ & $8 \%(24)$ & $5 \%(16)$ & $1 \%(2)$ \\
\hline \multicolumn{6}{|c|}{ Student head count $(n=304)$} \\
\hline 0-5000 students & $\begin{array}{l}5001-10,000 \\
\text { students }\end{array}$ & $\begin{array}{l}10,001-20,000 \\
\text { students }\end{array}$ & \multicolumn{2}{|l|}{$\begin{array}{l}>20,000 \\
\text { students }\end{array}$} & \\
\hline $22 \%(68)$ & $14 \%(42)$ & $21 \%(63)$ & $43 \%(131)$ & & \\
\hline \multicolumn{6}{|c|}{ Number of librarians (with MLS) $(n=305)$} \\
\hline $1-5$ & $6-10$ & $11-15$ & $16-20$ & $20-25$ & $>25$ \\
\hline $19 \%(59)$ & $20 \%(62)$ & $11 \%(35)$ & $10 \%(29)$ & $9 \%(28)$ & $30 \%(92)$ \\
\hline
\end{tabular}




\begin{tabular}{|c|c|c|c|}
\hline \multicolumn{4}{|l|}{$\begin{array}{c}\text { TABLE } 2 \\
\text { Self-Reported Confidence in Research Skills }\end{array}$} \\
\hline \multicolumn{4}{|c|}{$\begin{array}{l}\text { If you were told you had to publish a peer reviewed articles in the next two years how would you } \\
\text { rate your research skills? }\end{array}$} \\
\hline ( 1 = pure panic through 5 = very confident): & Mode & Median & Mean \\
\hline Performing a literature search $(n=304)$ & 5 & 5 & 4.58 \\
\hline Writing a manuscript suitable for submission $(n=303)$ & 5 & 5 & 4.34 \\
\hline Selecting an appropriate journal for manuscript submission $(n=303)$ & 5 & 5 & 4.27 \\
\hline $\begin{array}{l}\text { Negotiating the submission process from comments to signing a contract } \\
(\mathrm{n}=304)\end{array}$ & 5 & 4 & 4.09 \\
\hline Formulating a research question $(n=304)$ & 4 & 4 & 3.89 \\
\hline Time management $(n=304)$ & 5 & 4 & 3.87 \\
\hline Developing an IRB proposal $(n=303)$ & 5 & 4 & 3.68 \\
\hline Coming up with an idea that merits publication $(n=304)$ & 5 & 4 & 3.66 \\
\hline Creating a valid survey $(n=303)$ & 4 & 4 & 3.41 \\
\hline $\begin{array}{l}\text { Conducting basic analysis of quantitative data (median, mode, percentages, } \\
\text { etc. }(n=303)\end{array}$ & 5 & 3 & 3.36 \\
\hline Analyzing qualitative data $(n=304)$ & 4 & 3 & 3.26 \\
\hline Writing a proposal for funding (internal or external) $(n=303)$ & 3 & 3 & 2.89 \\
\hline Analyzing data using statistical tests (t-test, chi-squared, ANOVA, etc.) $(n=304)$ & 1 & 2 & 2.25 \\
\hline
\end{tabular}

\section{Institutional Expectations and Support for Research}

When applying for tenure or promotion, publication of peer-reviewed articles is required by 53 percent of the respondents and recommended by an additional 37 percent. This is a large increase from a 2005 survey, where only 30 percent of the respondents were required to conduct research but not as high as the 60 percent noted in a 2011 study or a recent study that found all respondents were required to do research for promotion or tenure. ${ }^{34}$ Peer-reviewed articles are less important for annual performance evaluations, with only 11 percent requiring publication of peer-reviewed articles for annual review and 59 percent recommending them.

When asked what kind of institutional support was needed to support their research, 78 percent of the respondents claim they need regular time for research during the week. A survey of ARL libraries found that the top institutional means of support were funding and time for research, followed closely by mentorship. ${ }^{35}$ When compared to a 2007 study, time allocations for research appear to be decreasing. The majority of librarians in that study reported having an average time allocation of 10 to 14 percent for scholarship, though the range was from less than 5 percent to more than 40 percent. ${ }^{36}$ As shown in table 3 , the current study found that 39 percent of librarians had no formal time allocation for research. Of those who did have formal allocations, 38 percent had less than 10 percent of their formal annual job assignment allocated to research. This decrease in time spent on research may have to do with an increasing amount of time being dedicated to librarianship duties and prioritizing what is more important. One respondent commented, "Although this time is available to me, I find that I am too busy to actually take it. It's been a real stumbling block in terms of working on research projects." Another respondent highlighted another important point that differentiates formal time allocation as a percentage of effort versus time spent actually working on 
research. "Research is part of our tenure process (40\% librarianship/teaching, 40\% scholarship/ research and $20 \%$ service) but we do not have a specific allocation of time for it i.e. 2 hours a week, 2 weeks a year, etc. We have to find time in our own schedule to make it happen. Also, the $\%$ allocation listed above does not necessarily correlate to time spent on each task which is made clear during any discussion of tenure. This means it counts for $40 \%$ of what I will be evaluated on but I don't get to spend $40 \%$ of my time on it."

Regardless of status, size of university, stage of career, or even the desire to do research, formal time allocations do not always represent reality. As it was put by one respondent, “Our allocation of effort for scholarship is $20 \%$, but this doesn't equate to time." Respondents were asked to approximate how much time each week (on average) they were able to devote to research. Time devoted to research varies depending on the stage of the research project or the time of the semester. Fifty-eight respondents indicated that they averaged one to five hours a week of personal time working on their research. One respondent illustrates a type of scenario for this. "During the first half of the semester, it tends to be on my own time. In the summer and in November and December, I can often do quite a bit on the clock."

\begin{tabular}{|c|c|c|c|c|c|c|}
\hline & & $\begin{array}{r}\text { TAB } \\
\text { Time for }\end{array}$ & $\begin{array}{l}\text { E } 3 \\
\text { esearch }\end{array}$ & & & \\
\hline Does your library provi & a formal al & cation of ti & he for resea & $\operatorname{rch}(n=205) ?$ & & \\
\hline I have no work time alloc & ed to researc & & $39 \%(80)$ & & & \\
\hline Less than $5 \%$ annually & & & $18 \%(36)$ & & & \\
\hline 5-9\% annually & & & $5 \%(11)$ & & & \\
\hline $10 \%$ annually & & & $18 \%(36)$ & & & \\
\hline $11-14 \%$ annually & & & $2 \%(5)$ & & & \\
\hline $15 \%$ annually & & & $5 \%(11)$ & & & \\
\hline $16-20 \%$ annually & & & $9 \%(18)$ & & & \\
\hline More than $20 \%$ annually & & & $4 \%(8)$ & & & \\
\hline In actual practice, how & ny hours $p$ & week (on a & erage) do y & ou spend on & esearch? & \\
\hline & Zero & One & Two & Three-Five & Six-Ten & $>$ Ten \\
\hline Work time $(n=212)$ & $16 \%(34)$ & $28 \%(59)$ & $22 \%(46)$ & $22 \%(47)$ & $8 \%(17)$ & $4 \%(9)$ \\
\hline Personal time $(n=210)$ & $30 \%(64)$ & $19 \%(40)$ & $20 \%(41)$ & $19 \%(40)$ & $8 \%(16)$ & $4 \%(9)$ \\
\hline
\end{tabular}

Table 4 illustrates the resources available to respondents. Again, the results are listed here in order of greatest perceived need, not the order in which they were presented. When asked to choose one resource that would be most helpful to improve their publication success, half of the respondents chose regular research time during the week (see table 5). Considering the high number of respondents at doctoral institutions (73\%) and the heavy emphasis on publishing (90 percent require or recommend publishing for promotion or tenure), time for research does appear to be an issue for many of the respondents in this survey. Opinions vary as to how time might be structured, but the theme of not having enough time remains the same. Having flexibility to set one's own schedule to work on research is important to many librarians and may be a positive factor in higher research productivity. Participants stressed the importance of time management. Successful authors suggested trying to set a specific time every day or at least every week to write and set personal deadlines. As one respondent said, "Avoid 
procrastination, just do it, buckle down, get 'er done." Another respondent who had recently received tenure commented on the need for nontenured librarians to "work very hard against research and job creep; instead, lobby/negotiate for time to perform research during work hours OR cut back on 'lesser' library work duties and make work time to perform research."

\begin{tabular}{|l|c|}
\hline \multicolumn{2}{|c|}{ TABLE 4 } \\
Institutional Support \\
\hline \multicolumn{2}{|c|}{} \\
\hline Regular time for research during the week & $\begin{array}{l}\text { Institutional support needed } \\
\text { for research (n=198) }\end{array}$ \\
\hline Data analysis support & $78 \%(154)$ \\
\hline Funding for travel related to gathering or presenting research & $67 \%(133)$ \\
\hline Grant writing training and support & $57 \%(112)$ \\
\hline Sabbaticals or formal research leave & $55 \%(108)$ \\
\hline Funding for non-travel related expenses & $45 \%(90)$ \\
\hline IRB training and support & $43 \%(86)$ \\
\hline Ability to participate in a collegial research support group & $42 \%(84)$ \\
\hline Writing/editing support & $40 \%(80)$ \\
\hline Formal mentorship & $37 \%(73)$ \\
\hline Informal mentorship & $32 \%(64)$ \\
\hline
\end{tabular}

Respondents to this survey were asked if they had taken a sabbatical and, if not, why they had not. Sixty-eight percent of those working at institutions that offer sabbaticals have not taken one. Many cited ineligibility; sabbaticals were only offered after tenure or after a specific number of years at the institution. Others feel as though they do not have time to do so because of other responsibilities, or that they did not have a project worthy of taking a sabbatical. Some librarians struggle to compete with other faculty at their university for these opportunities.

Collegial support is a growing trend in higher education, and librarians are also choosing to collaborate more. ${ }^{37}$ Many respondents to this survey felt that having a good coauthor was a primary means of success. One librarian highlighted the benefits of "having a co-author who is strong in idea generation, data collection, analysis and editing while I am strong in the literature review, writing, and dealing with the submission process. We are a team and our collaboration produces higher quality research than either of us could do alone." When early-career academic librarians were asked what was most helpful for their research success, collaboration was mentioned most often. ${ }^{38}$

Mentoring, whether formal or informal, has become a successful form of support for librarians. A study by Vilz and Poremski found that 80 percent of librarians agreed that having a mentor would be helpful. ${ }^{39}$ Mentorship opportunities give people opportunities to brainstorm ideas, ask questions, and get feedback or even vent frustrations. There is a benefit to creating a supportive environment and interacting with librarians who have experience and are actively involved in research. ${ }^{40}$ Although mentoring was not ranked here as a top need for institutional support, several comments in this study mention the benefits of mentoring. As one respondent noted, "Find a mentor, whether formal, informal, or simply a senior colleague...to 1) hold you accountable and keep you moving forward, and 2) to offer meaningful 


\begin{tabular}{|c|c|}
\hline \multicolumn{2}{|l|}{$\begin{array}{c}\text { TABLE } 5 \\
\text { Support Needed }\end{array}$} \\
\hline \multicolumn{2}{|c|}{$\begin{array}{l}\text { If you had to choose ONE thing your institution could do to make you a successful publisher what } \\
\text { would it be? }(n=202)\end{array}$} \\
\hline Regular time for research during the week & $50 \%(101)$ \\
\hline Data analysis support & $15 \%(30)$ \\
\hline Funding for travel related to gathering or presenting research & $8 \%(17)$ \\
\hline Sabbaticals or formal research leave & $6 \%(13)$ \\
\hline Formal mentorship & $5 \%(11)$ \\
\hline Ability to participate in a collegial research support group & $4 \%(8)$ \\
\hline Writing/editing support & $3 \%(7)$ \\
\hline Funding for non-travel related expenses--student assistants, etc. & $3 \%(7)$ \\
\hline Grant writing training and support & $3 \%(6)$ \\
\hline Informal mentorship & $1 \%(2)$ \\
\hline IRB training and support & $0 \%(0)$ \\
\hline
\end{tabular}

advice, support, and constructive criticism." This may indicate that academic librarians are satisfied with the mentoring support that they are already receiving, with 29 percent of the respondents participating in formal mentoring and 51 percent reporting informal mentoring relationships.

\section{Motivation to Conduct Research}

Kennedy and Brancolini discuss the shift in LIS literature from looking at barriers and challenges to focusing on factors that lead to research success. ${ }^{41}$ Tenure and promotion expectations or annual review evaluations may be an initial motivation for doing research, but many times librarians find that they actually enjoy doing research. Many research practitioners find that the work they do improves their skills as librarians and can also improve practices for others. When people see practical applications of what they are doing, it may seem more worthwhile and less cumbersome. There is also pride in being able to contribute to the profession and have an impact beyond one's own institution. Participants were asked to give their opinions on their personal attitudes toward publishing. As seen in table 6, most respondents remain enthusiastic about publishing and feel that their work has an impact on the profession. Those

\begin{tabular}{|l|c|c|c|}
\hline \multicolumn{3}{|c|}{ Attitudes towards Publishing } & \multicolumn{2}{|c|}{} \\
\hline \multicolumn{2}{|c|}{} & & \\
\hline $\begin{array}{l}\text { Please rate how enthusiastic you are about scholarly publishing. (n=212) } \\
\text { (1=Not at all enthusiastic, and 5=Love it!) }\end{array}$ & 4 & 4 & 3.7 \\
\hline $\begin{array}{l}\text { Do you believe your research has had a positive effect on the operation of the } \\
\text { library, the services and resources offered, or other value?) (n=213) } \\
\text { (1=No value, and 5=Highest value) }\end{array}$ & 4 & 4 & 3.76 \\
\hline $\begin{array}{l}\text { If you are tenured or have reached your highest level of promotion, do you still } \\
\text { feel MOTIVATED to publish? (n=85) (1=Yes, very much so, and 5=No, not at all) }\end{array}$ & 1 & 2 & 2.15 \\
\hline $\begin{array}{l}\text { If you are tenured or have reached your highest level of promotion, do you still } \\
\text { feel PRESSURED to publish? (n=84) (1=Yes, very much so, and 5=No, not at all) }\end{array}$ & 2 & 3 & 3.12 \\
\hline
\end{tabular}


who are tenured feel some pressure to continue publishing but are also still highly motivated to publish.

\section{Research Productivity}

Previous studies of library science authorship have suggested average article production; although date ranges vary, several reports considered prolific authors to have at least three refereed articles in five years and as many as 5 to 10 articles..$^{42}$ Using these studies as a guide, the authors divided the survey participants' responses on article publishing productivity into two categories. Low or average productivity was listed as having fewer than five library science articles published in the 10-year survey timeframe. Very high productivity was considered as those who had more than five articles published during the 10-year timeframe.

Table 7 shows that most respondents (36\%) had published between three and five articles in that time. Although this survey looked at journal articles as a means of measuring research productivity, the authors recognize that other modes of publication such as book chapters and presentations are also common and acceptable, and adding those into the results would have undoubtedly have shown increased levels of productivity. That said, 18 percent of the respondents had published more than five articles in a 10-year span, which, for the purpose of this study, would categorize them as highly productive.

\begin{tabular}{|c|c|c|c|c|c|c|}
\hline \multicolumn{7}{|c|}{$\begin{array}{c}\text { TABLE } 7 \\
\begin{array}{c}\text { Productivity: Approximate Number of Peer Reviewed Articles Published } \\
\text { in the Last Ten Years }\end{array}\end{array}$} \\
\hline & 0 & 1 & 2 & 3-5 & $6-10$ & $>10$ \\
\hline In library science journals $(n=214)$ & $2 \%(5)$ & $24 \%(51)$ & $20 \%(42)$ & $36 \%(77)$ & $14 \%(30)$ & $4 \%(9)$ \\
\hline $\begin{array}{l}\text { In journals outside the field of } \\
\text { library science }(n=213)\end{array}$ & $68 \%(144)$ & $18 \%(39)$ & $6 \%(13)$ & $6 \%(13)$ & $1 \%(3)$ & $<1 \%(1)$ \\
\hline
\end{tabular}

Pearson chi-squared analyses were used to look for potential relationships between publishing productivity and variables relating to demographics, confidence, or available support. No significant differences were found between most of the variables. Comparisons of publishing productivity with demographics such as type of institution (ARL, doctoral, master's, baccalaureate, or associate), faculty status, institution size, and age did not show significant relationships. Having various types of support available to the researcher (mentoring, formal time allocations, funding, and so on) also showed no relationship to publishing productivity. In this study, taking a research methods course or publishing a thesis did not show a significant relationship to publishing productivity. This differs from the Kennedy and Brancolini study, which found a significant correlation between conducting research and writing a thesis. ${ }^{43}$ However, like the Kennedy and Brancolini study, there was a relationship in this study between publishing productivity and having a second master's degree. ${ }^{44}$ There was also a relationship between publishing productivity and motivation. Although having a formal allocation of time in a job assignment did not prove to be related to publishing productivity $-\chi^{2}(5, \mathrm{~N}$ $=200)=7.064, \mathrm{Q}=.213$ - publishing productivity was related to using work or personal time for research. It would seem that, regardless of the reason, many librarians highly value doing research and publishing and make it a priority, whether it is formally written into their job assignment or whether there is a more informal expectation for it. Some librarians feel like it 
is just another part of their job and make time for it like any other responsibility. In response to the question about whether their institution provided formal allocations of time to conduct research there were many responses similar to this, "No formal allocation of percent of time but it is considered part of our regular workload."

Previous studies have reported that ARL libraries tend to be slightly more productive than non-ARL libraries, and tenure requirements may play a role in that.$^{45}$ Interestingly, this study found a significant relationship between productivity at institutions that count peerreviewed articles as part of their annual reviews but did not see the same relationship between productivity and those counting peer-reviewed articles for promotion and tenure: $\chi^{2}(2, N=$ $190)=3.120, \mathrm{Q}=.220$. This may be an indicator of a shift in expectations for scholarly publishing among academic librarians.

Survey participants were also asked to rank their confidence in particular research skills. Table 8 illustrates the research skills that showed a significant relationship to publishing productivity. The strongest relationships were for confidence in using statistical tests for analysis and confidence creating a valid survey.

Research behaviors that may lead to increased success were listed in the survey, and respondents were asked to select all the behaviors that they had adopted. The behavior chosen by most was reading the scholarly literature to keep up with trends and to identify areas where research was needed. This was followed by asking a colleague to read over their manuscript and provide feedback prior to submission. Participants commented on the need to play to one's

\section{TABLE 8}

Characteristics Showing a Significant Relationship to the Independent Variable of Publishing Productivity* (significance level = .05)

\begin{tabular}{|l|c|c|c|c|}
\hline Demographics (dependent variable): & $\mathbf{X}^{\mathbf{2}}$ & $\mathbf{N}$ & $\mathbf{d f}$ & $\mathbf{P}$ \\
\hline $2^{\text {nd }}$ masters' degree & 7.383 & 209 & 1 & .007 \\
\hline Counting peer-reviewed articles in annual review & 7.228 & 193 & 2 & .027 \\
\hline Motivation for publishing & 17.262 & 83 & 4 & .001 \\
\hline Enthusiasm for publishing & 14.690 & 207 & 4 & .006 \\
\hline Using work time to publish & 23.495 & 208 & 3 & .000 \\
\hline Using personal time to publish & 13.001 & 206 & 3 & .006 \\
\hline Self-reported confidence (dependent variable): & $\mathbf{X}^{\mathbf{2}}$ & $\mathbf{N}$ & $\mathbf{d f}$ & $\mathbf{P}$ \\
\hline Using statistical tests for analysis & 42.514 & 208 & 4 & .000 \\
\hline Creating a valid survey & 28.701 & 207 & 4 & .000 \\
\hline Coming up with an idea that merits publication & 25.101 & 208 & 4 & .000 \\
\hline Conducting a basic analysis of quantitative data & 22.630 & 208 & 4 & .000 \\
\hline Analyzing qualitative data & 22.093 & 208 & 4 & .000 \\
\hline Formulating a research question & 21.296 & 208 & 4 & .000 \\
\hline Developing an IRB proposal & 18.054 & 207 & 4 & .002 \\
\hline Time management & 13.130 & 208 & 4 & .010 \\
\hline Writing skills & 10.616 & 207 & 3 & .017 \\
\hline Writing a proposal for funding & 10.006 & 207 & 4 & .039 \\
\hline *High productivity defined as more than 5 articles in 10 years. Low productivity defined as 5 or fewer \\
\hline articles in 10 years. & & & \\
\hline
\end{tabular}


internal strengths such as good writing skills, perseverance, creativity, and curiosity. Table 9 lists the behaviors in the order of greatest use by the respondents, not the order in which they were presented. Respondents were encouraged to select all behaviors that they employed.

\begin{tabular}{|c|c|}
\hline \multicolumn{2}{|l|}{$\begin{array}{l}\text { TABLE } 9 \\
\text { Research Behaviors }\end{array}$} \\
\hline \multicolumn{2}{|c|}{$\begin{array}{l}\text { Which behaviors do you personally adopt to increase success in publication (may select more than } \\
\text { one) }(n=209)\end{array}$} \\
\hline Read a lot of scholarly lit to keep up with trends and see research gaps & $140(67 \%)$ \\
\hline Ask a colleague to read over manuscript prior to submission & $130(62 \%)$ \\
\hline Write at home or away from the office & $109(52 \%)$ \\
\hline Regularly brainstorm with colleagues about research ideas & $98(47 \%)$ \\
\hline Look for co-authors & $92(44 \%)$ \\
\hline Try to devote a specified number of hours per week to research & $90(43 \%)$ \\
\hline Ask a colleague to edit grammar and writing style prior to submission & $78(37 \%)$ \\
\hline Write up interesting case studies I have worked on at my library & $68(33 \%)$ \\
\hline Ask a colleague to help with data analysis & $59(28 \%)$ \\
\hline
\end{tabular}

Based on this study, the following recommendations are made for best practices to increase productivity.

- Time management may be the number one skill for being a highly productive researcher. This seems to be the biggest struggle for people but may also be a key to success.

- Awareness of the current literature and trends is very important. When librarians can find gaps in the literature and create projects around those gaps, they may be more successful. If the topic is of interest and has a practical application, authors may be more passionate and enthusiastic, helping them complete projects and get them published.

- Persistence was also mentioned repeatedly. As people practice a skill, they tend to develop greater expertise and confidence, allowing the skills to become second nature.

- Collaboration is another behavior that many librarians feel contributes to their success as authors. This includes bouncing ideas off others, finding coauthors, or even being able to ask for help. Coauthors can help immensely with accountability and increase the opportunity to learn from one another.

\section{Conclusion}

Previous studies indicate that more than 60 percent of LIS programs require a research methods course, but having taken a research methods course did not significantly correlate to greater publishing productivity in this study. ${ }^{46}$ This leads to the question of whether MLS course content is too theoretical and does not require enough actual original research practice for graduates to confidently conduct scholarly research. If so, it appears we haven't made much progress since Stephenson's comment in 1990: "Although it would appear that students are given a reasonable introduction to the step-by-step process of research, it may be that they are not leaving school with a real understanding of how to make that process part of their professional lives." ${ }^{\prime 7}$ In this study, only 18 percent of the respondents were asked to conduct original research during their library graduate study. That there are significant correlations 
between productivity and having a second graduate degree may warrant additional analysis of LIS course content. ${ }^{48}$

Although many challenges remain for librarian authors, the results of this study provide publishing tips from academic librarians who are active scholars. Suggestions include good time management, regular writing sessions, and setting self-imposed deadlines. Authors recommend writing about ideas that you are passionate about and being willing to learn from constructive criticism by peers, reviewers, and journal editors. Don't underestimate the importance of networking and keep up with professional reading and activities that will help find new ideas and potential coauthors.

The significant relationship between confidence in research skills and publishing productivity found in this study argue for requiring more emphasis on research methods instruction as well as additional institutional support. In spite of the pressures and challenges involved in publishing, many of the participants in this survey showed at least an appreciation for, if not a love of, the research and publication process. As one author stated "Publication is an addiction."

\section{Future Studies}

As mentioned previously, a conscious decision was made to focus this study on peer-reviewed journal articles. The authors recognize that there are many other types of scholarly and creative works that are beneficial to the profession and appropriate for tenure and promotion. Additional studies that examine productivity of books, book chapters, presentations, and other creative works are welcomed. The respondents were primarily from the United States. It would be interesting to see if the attitudes observed here also hold true in other countries.

The wealth of comments about the state of publishing in librarianship also deserves more attention. Many of these authors feel that library publishing is overemphasized for tenure and promotion, leading to poor quality overall. However, others see the need to be active participants in the scholarly conversation if librarians are to be accepted and respected as members of the faculty. There is no question that the preparation, quantity, and quality of academic librarian publishing remains a topic of interest to many. 


\section{APPENDIX. Survey}

Note: Some of the questions in the survey were adapted from:

1. Fennewald, Joseph. "Research Productivity among Librarians: Factors Leading to Publications at Penn State." College E Research Libraries 69, no. 2 (2008): 104-16. doi:10.5860/crl.69.2.104.

2. Kennedy, Marie R., and Kristine R. Brancolini. "Academic Librarian Research: A Survey of Attitudes, Involvement, and Perceived Capabilities." College E Research Libraries 73, no. 5 (2012): 431-48. https://doi.org/10.5860/crl-276.

3. Meadows, Ken N., Selinda Adelle Berg, Kristin Hoffmann, Nazi Torabi, and Margaret Martin Gardiner. "A Needs-Driven and Responsive Approach to Supporting the Research Endeavours of Academic Librarians." Partnership: The Canadian Journal of Library and Information Practice and Research 8, no. 2 (2013). https://doi.org/10.21083/ partnership.v8i2.2776.

4. Schrader, Alvin M., Ali Shiri, and Vicki Williamson. "Assessment of the Research Learning Needs of University of Saskatchewan Librarians: A Case Study." College $\mathcal{E}$ Research Libraries 73, no. 2 (2012): 147-63. https://doi.org/10.5860/crl-235.

5. Smigielski, Elizabeth M., Melissa A. Laning, and Caroline M. Daniels. “Funding, Time, and Mentoring: A Study of Research and Publication Support Practices of ARL Member Libraries." Journal of Library Administration 54, no. 4 (2014): 261-76. https:// doi.org/10.1080/01930826.2014.924309.

Do you hold an MLS from an ALA-accredited library school (or equivalent)?

$\square$ Yes

$\square \quad$ No (end survey)

Please select the option that best fits your current position.

Academic Library Practitioner (For the purposes of this study, an academic library practitioner is defined as a person holding at least an MLS degree who provides reference, collection development, archival, technical services, administrative, or other student and faculty support services in a college or university library. The practitioner may teach courses as an adjunct professor but that is not their primary responsibility.)

$\square \quad$ Library School Faculty (For the purposes of this study, defined as a person who spends the majority of their working hours teaching graduate MLS students.) (end survey)

$\square \quad$ None of the above (end survey)

Approximately how long have you been an academic librarian practitioner? (combined number of years if you have changed positions)

$\square \quad$ Less than one year

$\square \quad 1-2$ years

$\square \quad 3-5$ years

6-10 years

$\square \quad 11-20$ years

$\square \quad$ More than 20 years 
Your current faculty status (please select the best fit):

$\square$ Professional or Administrative, not Faculty

$\square$ Faculty, tenure-track (or continuing contract), not yet tenured

$\square \quad$ Faculty, tenured (or continuing contract)

$\square$ Faculty, promotion earning but no options for tenure or continuing contract

$\square$ Faculty, no options for promotion within the position

$\square$ Other

Your current academic rank (please select the best fit):

$\square \quad$ Full Librarian / Full Professor (or equivalent)

$\square$ Associate Librarian / Associate Professor (or equivalent)

$\square$ Assistant Librarian / Assistant Professor (or equivalent)

$\square \quad$ Instructor Librarian (or equivalent)

$\square \quad$ Visiting Librarian (or equivalent)

$\square \quad$ Other

Approximately how long have you held your current rank?

$\square \quad$ Less than 1 year

$\square \quad 1-2$ years

$\square \quad 3-5$ years

$\square \quad$ More than 5 years

Is your current position considered:

$\square \quad$ Full-time (12 months)

$\square \quad$ Full-time (9 months)

$\square$ Part-time

$\square$ Other

What is your current age?

$\square$ Younger than 18 (end $\square \quad 46-50$ survey)

口 18-21 $\quad$ 51-55

$\square \quad 22-25 \square \quad 56-60$

$\square \quad 26-30 \quad 61-65$

$\square \quad 31-35 \quad \square \quad 66-70$

$\square \quad 36-40 \quad \square \quad$ Over 70

$\square \quad 41-45 \quad \square \quad$ Prefer not to answer

Do you have a graduate degree(s) other than your MLS?

$\begin{array}{ll}\square & \text { Yes } \\ \square & \text { No }\end{array}$

Please list your additional graduate degrees and their discipline(s). 
Location of your current institution:
$\square$ USA
Canada
- Mexico
Central America
口 South America
Europe
$\square$ Asia
$\square$ Africa
$\square$ Australia
$\square$ Other

Please describe your current college or university:

$\square$ Doctoral granting, ARL or CARL Member

- Doctoral granting, not a member of ARL or CARL

- Master's level only (no doctoral degrees offered)

- Baccalaureate level only (no graduate degrees offered)

$\square \quad$ Associate or professional degrees only (no baccalaureate or graduate degrees offered)

$\square$ Other

Size of your current institution (head count):

$\square$ Fewer than 1,000 students

1,000-2,000 students

- 2,001-5,000 students

5,001-10,000 students

10,001-20,000 students

$\square$ More than 20,000 students

Approximately how many professional librarians (holding an MLS) are there at your library? If you have multiple libraries within your institution, please provide the number in your building.

1-5

$6-10$

11-15

16-20

口 20-25

口 $\quad$ More than 25

Is publication of peer-reviewed journal articles important for promotion or tenure (or continuing contract) at your current institution?

$\square \quad$ Yes, required

$\square$ Yes, recommended

$\square \quad$ No, we are promotion or tenure earning but it is not considered for librarians

$\square \quad$ N/A, we are not promotion or tenure earning 
Is publication in peer-reviewed journals important for annual performance evaluations at your current institution?

$\square \quad$ Yes, required

$\square$ Yes, recommended

- No, we have annual performance evaluations but peer reviewed articles aren't considered for librarians

N/A, we don't have annual performance evaluations

Did you take at least one research methods course for your MLS degree?

$\square$ Yes, it was required

- Yes, it wasn't required but I took it anyway

$\square$ No, it was available but I chose not to take it

No, it wasn't available

Did you conduct original research to write a thesis or capstone research paper for your MLS degree?

口 Yes

$\square$ No

If you have additional graduate degrees, did you take at least one research methods course for your non-MLS graduate degree?

$\square \quad$ I don't have additional graduate degrees beyond the MLS

$\square$ Yes, it was required

$\square \quad$ No, it was available but I chose not to take it

$\square$ Yes, it wasn't required but I took it anyway

- No, it wasn't available

Did you conduct original research for a thesis, capstone research paper, or dissertation for an additional graduate degree other than your MLS?

$\square \quad$ I don't have additional graduate degrees beyond the MLS

口 Yes

$\square$ No

If you were told that you had to publish a peer-reviewed journal article within the next two years, how would you rate each of your research skills. Use the following scale: 1 = pure panic; $2=$ not very confident but I might muddle through; $3=$ neutral; $4=$ somewhat confident; $5=$ very confident

$\square$ Time management

$\square$ Performing a literature search

$\square$ Coming up with an idea that merits publication

- Formulating a research question

- Developing an Institutional Research Board (IRB)/Human Ethics Board proposal

$\square$ Writing a proposal for funding (either internal or external)

Creating a valid survey 
Conducting a basic analysis of quantitative data (mean, median, percentages, and so on)

- Analyzing quantitative data using statistical tests (t-test, chi-square, ANOVA, and the like)

$\square \quad$ Analyzing qualitative data

․ Writing a manuscript suitable for submission (proper format, writing style, grammar, and other aspects)

- Selecting an appropriate journal for manuscript submission

․ Negotiating the submission process from responding to comments, editing, and signing the contract

Counting those that are in press, have you published any PEER-REVIEWED journal articles within the last 10 years?
口 Yes
$\square \quad$ No (end survey)

Approximately how many peer-reviewed journal articles related to library science have you published within the last 10 years? (Include published and in press)
$\square \quad 0$
$\square 1$
$\square 2$
$3-5$
6-10
$\square$ More than 10

Approximately how many peer-reviewed journal articles OUTSIDE THE FIELD OF LIBRARY SCIENCE have you published within the last 10 years? (Include published and in press)

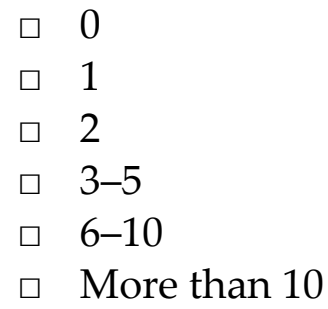

Does your library or institution provide a formal allocation of time for librarians to conduct research (in other words, is it in your formal job assignment)? If so, how much? I have no work time allocated to research-essentially all of my research and publication is done on my own time.

․ Less than $5 \%$ on average (annually)

$5 \%-9 \%$ on average (annually)

․ $10 \%$ on average (annually)

․ $11 \%-14 \%$ on average (annually)

․ $15 \%$ on average (annually)

$16 \%-20 \%$ on average (annually)

More than $20 \%$ on average (annually) 
In actual practice, how many hours a week (on average) of WORK TIME do you spend on research projects?

$\square \quad 0$ hours a week (I can't do research at work)

$\square \quad 1$ hour a week

2 hours a week

3-5 hours a week

6-10 hours a week

More than 10 hours a week

In actual practice, how many hours a week (on average) of PERSONAL TIME do you spend on research projects?

$\square \quad 0$ hours a week (I rarely or never work on my research outside of work hours)

$\square \quad 1$ hour a week

2 hours a week

3-5 hours a week

$6-10$ hours a week

$\square$ More than 10 hours a week

What kind of institutional support is AVAILABLE for your research? (check all that apply)

$\square$ Regular time for research during the week

口 Sabbaticals or formal research leave

$\square$ Formal mentorship

$\square \quad$ Informal mentorship

$\square \quad$ Ability to participate in a collegial research support group

$\square$ Funding for travel related to gathering or presenting research

$\square$ Funding for non-travel-related expenses-student assistance, supplies, and so on

- Institutional Research Board (IRB) / Human Ethics training and support

$\square$ Grant writing training and support

$\square$ Data analysis support

$\square$ Writing/editing support

What kind of institutional support is NEEDED for your research? (check all that apply)

$\square$ Regular time for research during the week

- Sabbaticals or formal research leave

$\square$ Formal mentorship

Informal mentorship

$\square$ Ability to participate in a collegial research support group

$\square$ Funding for travel related to gathering or presenting research

$\square$ Funding for non-travel-related expenses - student assistance, supplies, and the like

$\square$ Institutional Research Board (IRB) / Human Ethics training and support

$\square$ Grant writing training and support

$\square$ Data analysis support

$\square$ Writing/editing support 
If you had to choose ONE thing that your institution could do (or already does) to help you be a successful scholarly publisher, what would it be?

$\square$ Regular time for research during the week

$\square$ Sabbaticals or formal research leave

$\square$ Formal mentorship

$\square$ Informal mentorship

$\square$ Ability to participate in a collegial research support group

ㄷ Funding for travel related to gathering or presenting research

- Funding for non-travel-related expenses - student assistance, supplies, and the like

$\square$ Institutional Research Board (IRB) / Human Ethics training and support

$\square$ Grant writing training and support

$\square$ Data analysis support

$\square$ Writing/editing support

What behaviors do you personally adopt that you feel increases your success in publication? (please check all that apply)

$\square$ Read a lot of scholarly articles and books to keep up with trends and see gaps in the literature

$\square$ Look for coauthors

- Regularly brainstorm with colleagues about ideas that might make a good research project

- Write up interesting case studies I have worked on at my library

- Ask a colleague or colleagues to read over my manuscript and make suggestions prior to submission

$\square$ Ask a colleague or colleagues to help me with data analysis

$\square$ Ask a colleague to edit my manuscript for grammar and style prior to submission

- Try to devote a specified number of hours per week to my research pursuits

$\square$ Write at home or away from the office

Please add any additional behaviors you find to be advantageous to successful publishing:

If you had to select ONE thing that you think has made you a successful author, what would that be?

If sabbaticals and/or formal research leaves are available to you, have you taken any?

$\square$ Yes

$\square \quad$ No

- Sabbaticals and research leaves are not available to librarians at my institution

If sabbaticals or formal research leaves are available to you but you haven't taken any, why?

Using the scale below, please rate how enthusiastic you are about scholarly publishing. (Scale of $1=$ not at all enthusiastic to $5=$ love it!) 
Do you believe your research has had a positive effect on the operation of the library, the services and resources offered, or other value? (Scale of $1=$ no value to $5=$ highest value)

Are you currently tenured or at your highest level of promotion?

$\square$ Yes

$\square \quad$ No

If you are tenured or have reached your highest level of promotion, do you still feel PRESSURED to publish? (Scale of $1=$ Yes, very much so to $5=$ No, not at all)

If you are tenured or have reached your highest level of promotion, do you still feel MOTIVATED to publish? (Scale of $1=$ Yes, very much so to $5=$ No, not at all)

What do you enjoy most about publishing?

What do you enjoy least about publishing?

Are there any other comments or observations that you would like to make regarding research practices for academic librarians?

\section{Notes}

1. Selinda Adelle Berg, Heidi L.M. Jacobs, and Dayna Cornwall, "Academic Librarians and Research: A Study of Canadian Library Administrator Perspectives," College \& Research Libraries 74, no. 6 (2013): 560-72, https://doi. org/10.5860/crl12-366; Gay Helen Perkins and Amy J.W. Slowik, "The Value of Research in Academic Libraries," College E Research Libraries 74, no. 2 (2013): 143-57, https://doi.org/10.5860/crl-308.

2. Joseph Fennewald, "Research Productivity among Librarians: Factors Leading to Publications at Penn State," College \& Research Libraries 69, no. 2 (2008): 104-16, https://doi.org/10.5860/crl.69.2.104; Richard L. Hart, "Scholarly Publication by University Librarians: A Study at Penn State," College \& Research Libraries 60, no. 5 (1999): 454-62, https://doi.org/10.5860/crl.60.5.454; Ken N. Meadows et al., "A Needs-Driven and Responsive Approach to Supporting the Research Endeavours of Academic Librarians," Partnership: The Canadian Journal of Library and Information Practice and Research 8, no. 2 (2013), https://doi.org/10.21083/partnership.v8i2.2776; Alvin M. Schrader, Ali Shiri, and Vicki Williamson, "Assessment of the Research Learning Needs of University of Saskatchewan Librarians: A Case Study," College \& Research Libraries 73, no. 2 (2012): 147-63, https://doi.org/10.5860/crl-235.

3. Deborah D. Blecic et al., "Publication Patterns of U.S. Academic Librarians and Libraries from 2003 to 2012," College E Research Libraries 78, no. 4 (2017): 442-58, https://doi.org/10.5860/crl.78.4.442; Yu-Wei Chang, “Comparative Study of Characteristics of Authors between Open Access and Non-Open Access Journals in Library and Information Science," Library \& Information Science Research 39, no. 1 (2017): 8-15, https://doi.org/10.1016/j. lisr.2017.01.002; Quinn Galbraith et al., "Who Publishes in Top-Tier Library Science Journals? An Analysis by Faculty Status and Tenure," College $\mathcal{E}$ Research Libraries 75, no. 5 (2014): 724-35, https://doi.org/10.5860/crl.75.5.724; Stephen E. Wiberley Jr., Julie M. Hurd, and Ann C. Weller, "Publication Patterns of U.S. Academic Librarians from 1998 to 2002," College \& Research Libraries 67, no. 3 (2006): 205-16, https://doi.org/10.5860/crl.67.3.205.

4. Blecic et al., "Publication Patterns of U.S. Academic Librarians and Libraries from 2003 to 2012," 455; Howard Carter, Carolyn A. Snyder, and Andrea Imre, "Library Faculty Publishing and Intellectual Property Issues: A Survey of Attitudes and Awareness," portal: Libraries \& the Academy 7, no. 1 (2007): 72, https://doi.org/10.1353/ pla.2007.0003; Scott Seaman, "North American Institutions Most Frequently Represented in High-Impact Library Journals," LIBRES: Library \& Information Science Research Electronic Journal 18, no. 2 (2008): 13; Christopher Stewart, "Whither Metrics, Cont.: Assessing Publication Output of Academic Library Practitioners across Different Types of Institutions," Journal of Academic Librarianship 36, no. 6 (2010): 547, https://doi.org/10.1016/j.acalib.2010.08.021; William H. Walters and Esther Isabelle Wilder, "Worldwide Contributors to the Literature of Library and Information Science: Top Authors, 2007-2012," Scientometrics 103, no. 1 (2015): 311-13, https://doi.org/10.1007/s11192- 
014-1519-9; William H. Walters, “The Faculty Subculture, the Librarian Subculture, and Librarians' Scholarly Productivity," portal: Libraries $\mathcal{E}$ the Academy 16, no. 4 (2016): 828, https://doi.org/10.1353/pla.2016.0054; Wiberley, Hurd, and Weller, "Publication Patterns of U.S. Academic Librarians from 1998 to 2002," 212; Susan E. Wood and Betsy Park, "The Journal-Based Publishing Activity of Tennessee Academic Librarians: 2007-2011," Southeastern Librarian 61, no. 1 (2013): 5.

5. Kristin Hoffmann, Selinda Berg, and Denise Koufogiannakis, “Understanding Factors That Encourage Research Productivity for Academic Librarians," Evidence Based Library and Information Practice 12, no. 4 (2017): 105; Marie R. Kennedy and Kristine R. Brancolini, "Academic Librarian Research: A Survey of Attitudes, Involvement, and Perceived Capabilities," College \& Research Libraries 73, no. 5 (2012): 441, https://doi.org/10.5860/ crl-276; Meadows et al., "A Needs-Driven and Responsive Approach to Supporting the Research Endeavours of Academic Librarians," 16; Schrader, Shiri, and Williamson, "Assessment of the Research Learning Needs of University of Saskatchewan Librarians," 158; Amy J. Vilz and Molly Dahl Poremski, "Perceptions of Support Systems for Tenure-Track Librarians," College \& Undergraduate Libraries 22, no. 2 (Apr. 2015): 161, https://doi.org/ 10.1080/10691316.2014.924845; Wood and Park, "The Journal-Based Publishing Activity of Tennessee Academic Librarians: 2007-2011," 7.

6. Gaby Haddow and Jane E. Klobas, "Communication of Research to Practice in Library and Information Science: Closing the Gap," Library \& Information Science Research 26 (2004): 32, https://doi.org/10.1016/j.lisr.2003.11.010; Kennedy and Brancolini, "Academic Librarian Research: A Survey," 437.

7. Lili Luo, "Diversified Research Methods Education in LIS: Thinking outside the Box," Journal of Education for Library E Information Science 58, no. 2 (2017): 49, https://doi.org/10.12783/issn.2328-2967/58/2/1.

8. Phillip M. Edwards, Elaine Z. Jennerich, and Jennifer L. Ward, "Supporting a Culture of Library Research at the University of Washington at Seattle," in An Introduction to Staff Development in Academic Libraries, ed. Elizabeth Connor (New York, NY: Routledge, 2009), 81; Haddow and Klobas, "Communication of Research to Practice in Library and Information Science," 32; Mary Sue Stephenson, "Teaching Research Methods in Library and Information Studies Programs," Journal of Education for Library \& Information Science 31, no. 1 (1990): 61, https://doi.org/10.2307/40323727; Vicki Whitmell, "Building Research Competencies in Canadian Academic Libraries: The CARL Librarians' Research Institute," International Information \& Library Review 49, no. 3 (2017): 231-32, https://doi.org/10.1080/10572317.2017.1353379.

9. Kennedy and Brancolini, "Academic Librarian Research: A Survey," 437.

10. Marie R. Kennedy and Kristine R. Brancolini, "Academic Librarian Research: An Update to a Survey of Attitudes, Involvement, and Perceived Capabilities," College \& Research Libraries 79, no. 6 (2018): 834, https://doi. org/10.5860/crl.79.6.822.

11. Erin Ackerman, Jennifer Hunter, and Zara T. Wilkinson, "The Availability and Effectiveness of Research Supports for Early Career Academic Librarians," Journal of Academic Librarianship 44, no. 5 (2018): 562, https://doi. org/10.1016/j.acalib.2018.06.001.

12. Fennewald, "Research Productivity among Librarians," 109; Catherine Sassen and Diane Wahl, "Fostering Research and Publication in Academic Libraries," College \& Research Libraries 75, no. 4 (2014): 458, https://doi. org/10.5860/crl.75.4.458.

13. David Fox, "The Scholarship of Canadian Research University Librarians," Partnership: The Canadian Journal of Library \& Information Practice \& Research 2, no. 2 (2007): 6, https://doi.org/10.21083/partnership.v2i2.305; Shin Freedman, "Faculty Status, Tenure, and Professional Identity: A Pilot Study of Academic Librarians in New England," portal: Libraries and the Academy no. 4 (2014): 547-48, https://doi.org/10.1353/pla.2014.0023; Deborah B. Henry and Tina M. Neville, "Research, Publication, and Service Patterns of Florida Academic Librarians," Journal of Academic Librarianship 30, no. 6 (2004): 437, https://doi.org/10.1016/j.acalib.2004.07.006; Tina M. Neville and Deborah B. Henry, "Support for Research and Service in Florida Academic Libraries," Journal of Academic Librarianship 33 (2007): 78, https://doi.org/10.1016/j.acalib.2006.06.003; Perkins and Slowik, "The Value of Research in Academic Libraries," 151; Sassen and Wahl, "Fostering Research and Publication in Academic Libraries," 465-66.

14. Fennewald, "Research Productivity among Librarians," 110; David Fox, "Finding Time for Scholarship: A Survey of Canadian Research University Librarians," portal: Libraries and the Academy no. 4 (2007): 454, https:// doi.org/10.1353/pla.2007.0041; Henry and Neville, "Research, Publication, and Service Patterns of Florida Academic Librarians," 437; Neville and Henry, "Support for Research and Service in Florida Academic Libraries," 83; Perkins and Slowik, "The Value of Research in Academic Libraries," 151.

15. See as examples, Ackerman, Hunter, and Wilkinson, "The Availability and Effectiveness of Research Supports for Early Career Academic Librarians," 565; Edwards, Jennerich, and Ward, "Supporting a Culture of Library Research at the University of Washington at Seattle," 82; Fennewald, "Research Productivity among Librarians," 110. 
16. Ackerman, Hunter, and Wilkinson, "The Availability and Effectiveness of Research Supports for Early Career Academic Librarians," 565; Terry O'Brien and Kieran Cronin, "Research Output of Academic Librarians from Irish Higher Education Institutions 2000-2015: Findings from a Review, Analysis, and Survey," New Review of Academic Librarianship 22, no. 2/3 (2016): 215, https://doi.org/10.1080/13614533.2016.1181666.

17. Berg, Jacobs, and Cornwall, "Academic Librarians and Research," 565.

18. Fox, "Finding Time for Scholarship," 459; Sassen and Wahl, "Fostering Research and Publication in Academic Libraries," 471.

19. Ackerman, Hunter, and Wilkinson, "The Availability and Effectiveness of Research Supports for Early Career Academic Librarians," 559-60; Fennewald, "Research Productivity among Librarians," 112; Kennedy and Brancolini, "Academic Librarian Research: An Update," 837; O’Brien and Cronin, "Research Output of Academic Librarians from Irish Higher Education Institutions 2000-2015," 216.

20. Fennewald, "Research Productivity among Librarians," 106; Freedman, "Faculty Status, Tenure, and Professional Identity," 548; Christopher V. Hollister, "An Exploratory Study on Post-Tenure Research Productivity among Academic Librarians," Journal of Academic Librarianship 42, no. 4 (2016): 370, https://doi.org/10.1016/j. acalib.2016.04.021; Mary Kandiuk and Harriet M. Sonne de Torrens, "Academic Freedom and Librarians' Research and Scholarship in Canadian Universities," College \& Research Libraries 79, no. 7 (2018): 936, https://doi.org/10.5860/ crl.79.7.931; O'Brien and Cronin, "Research Output of Academic Librarians from Irish Higher Education Institutions 2000-2015," 215.

21. Fennewald, "Research Productivity among Librarians," 106; Hollister, "An Exploratory Study on PostTenure Research Productivity among Academic Librarians," 370.

22. Hollister, "An Exploratory Study on Post-Tenure Research Productivity among Academic Librarians," 371.

23. Berg, Jacobs, and Cornwall, "Academic Librarians and Research," 568; Fox, "The Scholarship of Canadian Research University Librarians," 6.

24. Hoffman, Berg, and Koufogiannakis, "Understanding Factors That Encourage Research Productivity for Academic Librarians," 113.

25. Ackerman, Hunter, and Wilkinson, "The Availability and Effectiveness of Research Supports for Early Career Academic Librarians," 560; Hoffman, Berg, and Koufogiannakis, "Understanding Factors That Encourage Research Productivity for Academic Librarians," 113; Meadows et al., "A Needs-Driven and Responsive Approach to Supporting the Research Endeavours of Academic Librarians," 9; Schrader, Shiri, and Williamson, "Assessment of the Research Learning Needs of University of Saskatchewan Librarians," 156.

26. See as examples: Rickey D. Best and Jason Kneip, "Library School Programs and the Successful Training of Academic Librarians to Meet Promotion and Tenure Requirements in the Academy," College E Research Libraries 71, no. 2 (2010): 107, https://doi.org/10.5860/0710097; Carter, Snyder, and Imre, "Library Faculty Publishing and Intellectual Property Issues," 72; O'Brien and Cronin, "Research Output of Academic Librarians from Irish Higher Education Institutions 2000-2015," 214; Wood and Park, "The Journal-Based Publishing Activity of Tennessee Academic Librarians: 2007-2011," 5.

27. Hoffman, Berg, and Koufogiannakis, "Understanding Factors That Encourage Research Productivity for Academic Librarians," 107.

28. Hollister, "An Exploratory Study on Post-Tenure Research Productivity among Academic Librarians," 373.

29. Blecic et al., "Publication Patterns of U.S. Academic Librarians and Libraries from 2003 to 2012," 453.

30. Wood and Park, "The Journal-Based Publishing Activity of Tennessee Academic Librarians: 2007-2011," 5 .

31. An attempt was made to contact the academic library or state library association for all fifty states; however, some lists require membership. Lists that received an invitation to the survey include: ACRL Scholarly Communication, ACRL University Libraries, ALA Community \& Junior Colleges, Section, Canadian ARL, Canadian Federation of Professional Academic Librarians, COLLDV, Info Lit Discussion List, LIBREF, Public Service Directors of Large Research Libraries, ACRL Alabama, Alabama Colleges Universities and Special Libraries Division, Alaska Library Association, Arkansas Library Association, Colorado Academic Library Association, Connecticut Libraries, Delaware Valley, Florida ACRL, Georgia Library Association, Hawaii Library Association, Idaho Library Association, Illinois ACRL, Kansas Library Association College and Universities Library Section, Kentucky Library Association, Main State Library Announcements, Missouri ACRL, Network of Alabama Academic Libraries, New England Library Association, New Jersey ACRL, New Mexico ACRL, North Dakota Library Association, Academic Library Association of Ohio, Pennsylvania Library Association, South Dakota Library Association, Southeastern Library Association, Tennessee Library Association, Texas Academic Libraries, Vermont College and Special Libraries, Vermont Library Association, Virginia Library Association, 
Washington ACRL, West Pennsylvania/West Virginia ACRL, and the Wyoming Library Association.

32. Hoffman, Berg, and Koufogiannakis, "Understanding Factors That Encourage Research Productivity for Academic Librarians," 107; Hollister, "An Exploratory Study on Post-Tenure Research Productivity among Academic Librarians," 373.

33. Kennedy and Brancolini, "Academic Librarian Research: A Survey," 436-37; Kennedy and Brancolini, "Academic Librarian Research: An Update," 832; Meadows et al., "A Needs-Driven and Responsive Approach to Supporting the Research Endeavours of Academic Librarians," 8.

34. Ackerman, Hunter, and Wilkinson, "The Availability and Effectiveness of Research Supports for Early Career Academic Librarians," 555; Neville and Henry, "Support for Research and Service in Florida Academic Libraries," 82; Sassen and Wahl, "Fostering Research and Publication in Academic Libraries," 465-66.

35. Elizabeth M. Smigielski, Melissa A. Laning, and Caroline M. Daniels, "Funding, Time, and Mentoring: A Study of Research and Publication Support Practices of ARL Member Libraries," Journal of Library Administration 54, no. 4 (2014): 264, https://doi.org/10.1080/01930826.2014.924309.

36. Fox, "The Scholarship of Canadian Research University Librarians," 8.

37. S. Adams Becker et al., NMC Horizon Report: 2017 Higher Education Edition (Austin, TX: The New Media Consortium, 2017), 2, available online at https://www.learntechlib.org/p/174879/report_174879.pdf [accessed 17 January 2019]; Munazza Jabeen, Liu Yun, Muhammad Rafiq, and Misbah Jabeen, "Research Productivity of Library Scholars: Bibliographic Analysis of Growth and Tends of LIS Publications," New Library World 116, no. 7/8 (2015): 449, https://doi.org/10.1108/NLW-11-2014-0132; Schrader, Shiri, and Williamson, "Assessment of the Research Learning Needs of University of Saskatchewan Librarians," 156.

38. Ackerman, Hunter, and Wilkinson, "The Availability and Effectiveness of Research Supports for Early Career Academic Librarians," 560.

39. Vilz and Poremski, "Perceptions of Support Systems for Tenure-Track Librarians," 158.

40. Fennewald, "Research Productivity among Librarians," 112.

41. Kennedy and Brancolini, "Academic Librarian Research: An Update," 824.

42. Blecic et al., "Publication Patterns of U.S. Academic Librarians and Libraries from 2003 to 2012," 453; O'Brien and Cronin, "Research Output of Academic Librarians from Irish Higher Education Institutions 2000-2015," 214; Walters and Wilder, "Worldwide Contributors to the Literature of Library and Information Science: Top Authors, 2007-2012," 317-18; Wood and Park, "The Journal-Based Publishing Activity of Tennessee Academic Librarians: 2007-2011," 5.

43. Kennedy and Brancolini, "Academic Librarian Research: An Update," 835.

44. Kennedy and Brancolini, "Academic Librarian Research: An Update," 838.

45. Best and Kneip, "Library School Programs and the Successful Training of Academic Librarians to Meet Promotion and Tenure Requirements in the Academy," 107; Blecic et al., "Publication Patterns of U.S. Academic Librarians and Libraries from 2003 to 2012," 453; Seaman, "North American Institutions Most Frequently Represented in High-Impact Library Journals," 14, 16.

46. Lili Luo, "Fusing Research into Practice: The Role of Research Methods Education," Library \& Information Science Research 33, no. 3 (2011): 191; Luo, "Diversified Research Methods Education in LIS," 49; Stephenson, "Teaching Research Methods in Library and Information Studies Programs," 54.

47. Stephenson, "Teaching Research Methods in Library and Information Studies Programs," 61.

48. Kennedy and Brancolini, "Academic Librarian Research: An Update," 838. 